This is the final peer-reviewed accepted manuscript of:

Giovanni Mastrolonardo, Ornella Francioso, Giacomo Certini

Relic charcoal hearth soils: A neglected carbon reservoir. Case study at Marsiliana forest, Central Italy

which has been published in final form in

Geoderma Volume 315, 1 April 2018, Pages 88-95

The final published version is available online at:

https://doi.org/10.1016/i.geoderma.2017.11.036

(C) 2017 Elsevier. This manuscript version is made available under the Creative Commons Attribution-NonCommercial-NoDerivs (CC BY-NC-ND) 4.0 International License (http://creativecommons.org/licenses/by-nc-nd/4.0/) 


\title{
Relic charcoal hearth soils: A neglected carbon reservoir. Case study at Marsiliana forest, Central Italy
}

\author{
Giovanni Mastrolonardo a, b, c, $*$, Ornella Francioso ${ }^{\mathrm{b}}$, Giacomo Certini $^{\mathrm{c}}$ \\ ${ }^{a}$ Department BIOSystem Engineering - Gembloux Agro-Bio Tech, University of Liege, Avenue Maréchal Juin 27, B-5030 Gembloux, Belgium \\ b Dipartimento di Scienze Agrarie, Università degli Studi di Bologna, V.le Fanin 40, 40127 Bologna, Italy \\ ${ }^{\mathrm{c}}$ Dipartimento di Scienze delle Produzioni Agroalimentari e dell'Ambiente (DISPAA), Università degli Studi di Firenze, Piazzale delle Cascine 28, 50144 Firenze, Italy
}

\begin{abstract}
A B S T R A C T
Charcoal production in forests is one of the oldest forms of forest exploitation. The legacy of such once widespread activity is a plethora of relic charcoal hearths $\left(\mathrm{RCHs}^{1}\right)$, where soil shows a thick, black, charcoal-rich top horizon. Even where very common, such as in European forests, RCHs were rarely studied to assess their relevance as $\mathrm{C}$ reservoir. For this purpose, as a case study, we investigated some RCHs at Marsiliana, a typical Mediterranean oak forest from Central Italy.

We found that RCHs soils, in spite of representing $<0.5 \%$ of total surface, gave a substantial contribution in terms of C, i.e. $1.1 \%$ to $4.2 \%$ of total ecosystem $\mathrm{C}$, including litter, the top $30 \mathrm{~cm}$ of soil, deadwood, aboveground and belowground biomass. On average, soil C content in RCHs was eight times higher than the soil outside the RCHs. The environmental significance of RCHs soils appears still greater considering that, on average, $43 \%$ of their C stock was charcoal, a form of C highly recalcitrant to mineralization. These results would stress the importance of accounting for the contribution of RCHs in terms of soil $\mathrm{C}$ and giving an estimation of their charcoal content in future $\mathrm{C}$ inventories, both as macroscopic and microscopic particles in soil. This study support the necessity of safeguarding the anthropogenic soils of RCHs as a precious $\mathrm{C}$ reservoir as well as a memory of past land uses.
\end{abstract}

Handling Editor: I. Kögel-Knabner

Keywords:

Pyrogenic carbon

Black carbon

Charcoal kilns

Biochar

Forest carbon inventory

Anthropogenic soils

\section{Introduction}

Charcoal production is one of the oldest form of forest exploitation, starting in the Neolithic and continuing to the present (Ludemann, 2010; Schenkel et al., 1998). Charcoal was, and is still, used for cooking, heating, smelting and steel-making (Antal \& Grønly, 2003). Usually, charcoal was directly made in forests by slowly burning in partially anoxic conditions wood piled in mounds (earth mounds) or amassed in pits (earth pits) and covered with leaves and earth at the very top (FAO, 1987; Schenkel et al., 1998). The legacy of such widespread, long-lasting activity is a plethora of abandoned charcoal production emplacements (kilns or, more properly, hearths), where the soil typically shows a thick, very dark charcoal-rich top horizon.

These relic charcoal hearths (hereafter called RCHs) are particularly common in Europe (Deforce et al., 2013; Ludemann, 2003) and are the subject of several studies. Most of such studies are based on anthraco- logical and radiocarbon analyses of charcoal particles, aiming at reconstructing past forests composition and exploitation (e.g. Deforce et al., 2013; Ludemann, 2003). Some other studies deal with the vegetation growing in relic charcoal hearths (e.g. Carrari et al., 2016a, 2016b; Hart et al., 2008; Mikan \& Abrams, 1996). Works focused on soils developed in RCHs were few until last decade (e.g. Mikan \& Abrams, 1995; Young et al., 1996). However, in recent years they increased much (e.g., Borchard et al., 2014; Criscuoli et al., 2014; Hardy et al., 2016, 2017; Heitkotter \& Marschner, 2015; Hernandez-Soriano et al., 2016; Kerré et al., 2016, 2017; Raab et al., 2017), probably as a consequence of the current huge interest in biochar, i.e. pyrolysed biomass (char) designed to be added to soils as enhancer of fertility and sink of C.

Nevertheless, a crucial question remains not completely addressed: how much carbon do anthropogenic soils of RCHs store and how much of this carbon is charcoal? This question is even more significant taking

\footnotetext{
* Corresponding author at: Department BIOSystem Engineering - Gembloux Agro-Bio Tech, University of Liege, Avenue Maréchal Juin 27, B-5030 Gembloux, Belgium. Email address: giovanni.mastrolonardo@uliege.be (G. Mastrolonardo)
} 
into account that charcoal is known as one of the most recalcitrant forms of $\mathrm{C}$ in the environment, especially when it occurs as macroscopic fragments (De Lafontaine \& Asselin, 2011). However, in spite of the apparent high content of macroscopic charcoal particles in these soils, most of the authors did not include this $\mathrm{C}$ fraction in the estimation of TOC. Some (e.g. Hardy et al., 2016; Heitkotter \& Marschner, 2015) did not distinguish charcoal $\mathrm{C}$ from the rest of $\mathrm{C}$, while other authors (e.g. Borchard et al., 2014; Hardy et al., 2017; Hernandez-Soriano et al., 2016; Kerré et al., 2016, 2017) discarded macroscopic charcoal particles along with the rock fragments, so taking into account for analysis (and the C assessment) just the charcoal in the "fine earth" - the $<2 \mathrm{~mm}$ fraction of the soil.

Finally, the importance of RCHs as C reservoirs is usually neglected despite their common presence in many regions throughout the world. $\mathrm{RCHs}$ are disregarded by the inventories of terrestrial C sources and sinks drawn up by the UN's Framework Convention on Climate Change (UNFCCC) in the Kyōto Protocol.

The hypothesis of this study is that RCHs are important $\mathrm{C}$ reservoirs that would deserve to be accounted for in the inventories of terrestrial C pools at regional or local level. For verifying such hypothesis, we quantified the total organic carbon (TOC) in some RCHs soils from the Marsiliana forest, a typical Mediterranean mixed oak forest where charcoal production was enduring and massive since at least the Middle Age (Costagliola et al., 2008). We determined the amount of charcoal, as both small particles in the fine earth and coarse particles in the skeleton. Finally, we made an estimate of the contribution of TOC from RCHs to the whole $\mathrm{C}$ stock of the forest, including biomass, dead wood, litter, and soil.

\section{Materials \& methods}

\subsection{Study area}

The study area is the Marsiliana forest, in the Massa Marittima municipality, southern Tuscany, Central Italy. This forest is approximately 2600 ha wide, it is located a few km away from the sea, 150-200 m a.s.l., and experiences Mediterranean climate, with a mean annual temperature of $15.7{ }^{\circ} \mathrm{C}$ and a mean annual precipitation of $741 \mathrm{~mm}$. The forest is a mature coppice dominated by evergreen oak (Quercus ilex L.) with ancillary presence of deciduous trees, such as Quercus cerris L., Quercus pubescens Willd, Quercus suber L. Fraxinus ornus L., Acer monspessulanum L., Sorbus domestica L., Sorbus torminalis L. The undergrowth is dense, dominated by Erica arborea L., Arbutus unedo L., Phillyrea latifolia L., and Myrtus communis L. The soil, which formed on a chaotic complex of scaly clays, marls, limestone, and sandstone, is loam-textured and shows an A-Bw-C sequence of horizons; it is a Dystric Cambisol according to the World Reference Base for Soil Resources (IUSS Working Group WRB, 2015).

The Marsiliana forest and the areas nearby were shaped through centuries by the activities related to charcoal production. Here charcoal was essential as source of energy and for metallurgy purposes (Mariotti Lippi et al., 2000). The region was extensively exploited for metal mining and smelting at least since the 1st Millennium BC under the Etruscans (Mariotti Lippi et al., 2000), or even back to the late Bronze Age (Costagliola et al., 2008 and the references therein). In the Middle Age and until the second half of the nineteenth century, the site was one of the most important centres for Fe processing (Costagliola et al., 2008). Once the mines were exhausted, charcoal production continued for domestic purposes for another century, until 1958. During that

\footnotetext{
1 RCHs: relic charcoal hearths.
}

period, the forest was managed as a short-rotation coppice, cut every 15-18 years.

A 16.1 ha wide portion of the forest was selected for this study. It comprised two distinct areas in terms of aspect and forest structure: the north-oriented area (hereafter called No), about 6.4 ha wide, showing significantly taller, older, and larger evergreen oak trees than the south-oriented area (hereafter called So), about 9.7 ha wide and showing substantially similar forest composition but thicker and more tangled undergrowth (Table 1). In total, we found 35 relic charcoal hearths, 19 in No and 16 in So (Fig. 1; S1). They were easy to find because characterized by both a gap in the tree canopy and a thick, black, charcoal-rich topsoil. In spite of several decades since abandonment, at least, many of these RCHs were well preserved. All RCHs were geo-referenced, described, and mapped (Fig. 1; S1). The size of the RCHs and the thickness of their charcoal-rich top horizon were measured (S1). The latter in some cases appeared split into two, with a thin B horizon in between, which could reveal two distinct phases of charring.

\subsection{Soil sampling}

Four of the best-preserved RCHs were chosen for the study, two in No and two in So (Fig. 1). The choice was chiefly driven by the thickness of the black top horizon. In fact, the four selected hearths differed in the thicknesses of the charcoal enriched layer, so to see if such a feature could be related with some RCHs properties. The black top horizon of the selected RCHs was 13 and $24 \mathrm{~cm}$ thick in So, and 22 and $26 \mathrm{~cm}$ thick in No. The last one, below a thin Bwb horizon (Raab et al., 2017), had another charcoal enriched horizon $16 \mathrm{~cm}$ thick that, however, was not included in the sampling.

All RCHs had elliptical shape, although the woodpiles were usually built with a circular base. The elliptical shape of RCH was probably due to the procedure used for collecting the charcoal, i.e. dragging it away by rakes from two opposed sides of the pile across the slope (Carrari et al., 2017). We took three soil samples per RCHs: one nearly from the centre of the ellipse, the other two ones along the axes, about one meters from the border of the RCHs (Fig. 1). For sampling the RCHs, we removed the litter layer, and then we excavated pits approximately $20 \times 20 \mathrm{~cm}$ wide and deep to the lower boundary of the black, charcoal-rich top horizon, so collecting 4 to $10 \mathrm{~kg}$ of soil from each pit. A single sample of "reference soil" (i.e., apparently not involved by any operation related to the carbonisation process) was taken about twenty metres out of each RCH and to the same depth as the average thickness of the samples from the related RCHs. In each pit, soil bulk density was determined by the "irregular hole method". Hence, the pits were filled with water poured in a graduate cylinder, using a nylon film to waterproof the walls of the pits, to measure their volume in the field. All the material from the pits was weighted after drying at $105{ }^{\circ} \mathrm{C}$ in the laboratory (Blake \& Hartge, 1986). Ten samples of litter layer were randomly collected throughout the study area (five samples in No and five in So), from inside a $40 \times 40 \mathrm{~cm}$ frame.

\subsection{Samples analysis and macro-charcoal isolation}

Soil and litter samples were oven-dried $\left(60^{\circ} \mathrm{C}\right)$ to constant weight. The soil samples were sieved to $2 \mathrm{~mm}$ to separate the fine earth ( $<2 \mathrm{~mm}$ particles) from the skeleton. This latter was mostly composed by rock and charcoal fragments less than few $\mathrm{cm}$ in size. The skeleton was further separated into rock and charcoal fragments by combined floatation and hand picking. Both of them were finally dried $\left(60{ }^{\circ} \mathrm{C}\right)$ to constant weight and their mass determined.

Total $\mathrm{C}$ in the fine earth was measured by dry combustion (by a CHNS-O mod. EA 1110, Thermo-Fisher) on about 5-15 mg of sample 
Table 1

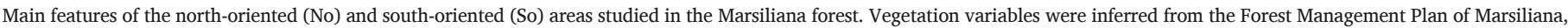
based on a field campaign performed in 2013. Double numbers refer to minimum and maximum of the range.

\begin{tabular}{|c|c|c|c|c|c|c|c|c|c|}
\hline $\begin{array}{l}\text { Study } \\
\text { area }\end{array}$ & Surface & Hearths & Aspect & Slope & $\begin{array}{l}\text { Age class of } \\
\text { trees }\end{array}$ & $\begin{array}{l}\text { Mean height } \\
\text { of trees }\end{array}$ & $\begin{array}{l}\text { Mean diameter } \\
\text { of trees }\end{array}$ & $\begin{array}{l}\text { Oak } \\
\text { stools }\end{array}$ & $\begin{array}{l}\text { Mean tree } \\
\text { volume }\end{array}$ \\
\hline & ha & $\mathrm{n}$ & & $\%$ & years & $\mathrm{m}$ & $\mathrm{cm}$ & $\mathrm{nha}^{-1}$ & $\mathrm{~m}^{3} \mathrm{ha}^{-1}$ \\
\hline No & 6.4 & 19 & $\mathrm{NE}$ & $15-30$ & $61-80$ & $10-12$ & $12-15$ & $>3.500$ & $125-175$ \\
\hline So & 9.7 & 16 & S-SE & $5-20$ & $21-30$ & $6-10$ & $5-10$ & $>3.500$ & $50-100$ \\
\hline
\end{tabular}

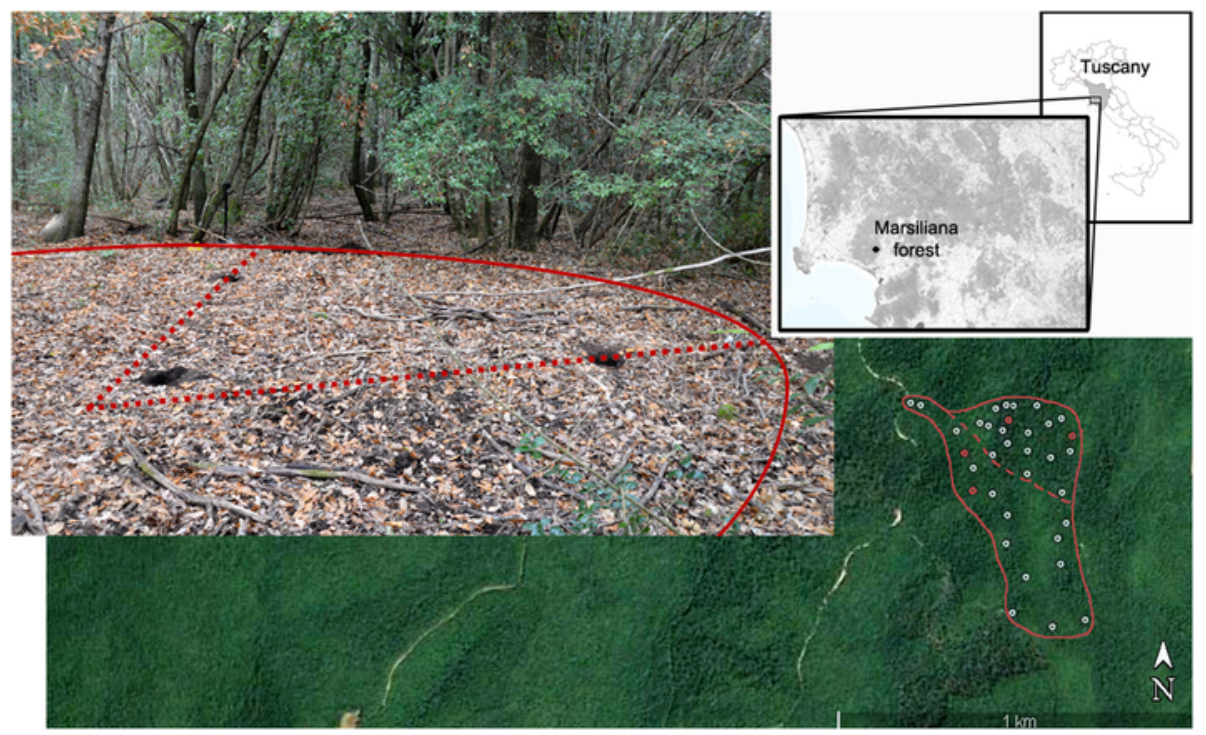

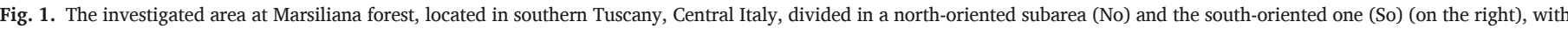

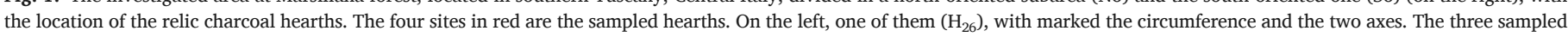
pits are visible. (For interpretation of the references to color in this figure legend, the reader is referred to the web version of this article.)

taken from a finely ground (ball-milled) aliquot. For determining the average C content of the coarse charcoal, three particles were randomly taken from each hearth's pit, mixed all together and pulverised. Three aliquots of the powder underwent analysis by dry combustion. The average $\mathrm{C}$ content of the litter layer was measured in triplicate on ground aliquots of the mix of all samples, from both No and So areas.

The total organic carbon (TOC) concentration of the RCH soil was expressed as grams of $\mathrm{C}$ per $\mathrm{kg}$ of bulk soil, hence including also the skeleton, so rich in charcoal particles. This choice based on the consideration that otherwise the substantial amount of $C$ in form of coarse charcoal would be neglected, as the skeleton is usually discarded in soil analyses. Hence, the bulk soil TOC we refer to hereafter in the text is the sum of the OC in the fine earth - as both native uncharred OC and the $<2 \mathrm{~mm}$ charcoal fragments - and the OC in the coarser charcoal fragments.

\subsection{Determination of charcoal in the fine earth $(<2 \mathrm{~mm}$ fraction)}

There are several methods available in literature to evaluate the content of charcoal - here and after intended as pyrogenic carbon (PyC), a continuum of organic compounds ranging from partially charred biomass to soot (Bird \& Ascough, 2012) - in soil, sediments and aerosol (Currie et al., 2002; Hammes et al., 2007; Roth et al., 2012). However, no one of them is able to account for the whole range of charcoal compounds and in fact the different methods differ in terms of target region within this range (Currie et al., 2002; Hammes et al., 2007; Roth et al., 2012). We used the method proposed by Kurth et al. (2006) - in triplicate, for soils from both inside and outside the RCHs
- because of its simplicity and good repeatability. This method, called "weak acid digestion" method, exploits the proneness of all organic materials except the charred ones to a $\mathrm{H}_{2} \mathrm{O}_{2}(30 \% \mathrm{w} / \mathrm{w})+\mathrm{HNO}_{3} 1 \mathrm{M}$ treatment at $100{ }^{\circ} \mathrm{C}$ for $16-20 \mathrm{~h}$, i.e. until evident effervescence in the solution ends, so indicating the completion of the digestion. The mass of organic carbon in the residue was assumed to be charcoal. However, Maestrini \& Miesel (2017) have shown that this method unavoidably implies oxidation of some charcoal as well. Therefore, to have information about a more precise charcoal recovery, we built a calibration curve pulverising a mix of charcoal particles from all studied RCHs and combining it with pure quartz to obtain the following charcoal concentrations: $10,20,40,60,80$ and $100 \%$.

\subsection{Forest carbon estimation}

According to the Good Practice Guidance for Land Use, Land-Use Change and Forestry (GPG-LULUCF) of the IPCC (Penman et al., 2003), forest ecosystems have five different $\mathrm{C}$ pools: i) aboveground biomass; ii) belowground biomass; iii) deadwood; iv) litter; v) soil organic matter.

The sum of the above- and below-ground biomass, was estimated according to the following equation (Penman et al., 2003):

$C_{\text {biomass }}=\left(V^{*} D^{*} B E F_{2}\right)^{*}(1+R)^{*} C F$

where $\mathrm{C}_{\text {biomass }}$ is tonnes of carbon in the whole biomass, $V$ is the merchantable volume $\left(\mathrm{m}^{3} \mathrm{ha}^{-1}\right), D$ is the wood density (tonnes of dry matter $\mathrm{m}^{-3}$ ), $B E F_{2}$ is the 'biomass expansion factor' for converting the 
merchantable volume into aboveground tree biomass (dimensionless), $R$ and $C F$ the root-to-shoot ratio and carbon-to-biomass ratios, respectively (dimensionless). The data of merchantable volume $(V)$ was taken from the Forest Management Plan of Marsiliana, dated 2013. The other factors of Eq. (1), i.e. mean density $(D)$, biomass expansion factor $\left(B E F_{2}\right)$, root-to-shoot ratio $(R)$, and carbon fraction $(C F)$, were not available for Marsiliana. Hence, they were inferred from papers dealing with forests as similar as possible to the one studied here, i.e. an evergreen mixed coppice oak forest having a mean $D$ of $0.72 \mathrm{Mg} \mathrm{m}^{-3}$ and $B E F_{2}$ of 1.45 (Vitullo et al., 2008). For the root-to-shoot ratio, we referred to a mixed coppice of evergreen oak, Arbutus unedo, and Erica arborea, with $R=0.45$ (Gratani et al., 1980). The carbon fraction ( $C F)$ of biomass is a fairly constant value, 0.5 according to GPG-LULUCF (Penman et al., 2003). Finally, deadwood estimation based on the Italian National Forest Inventory (INFC, 2011).

Litter and soil $\mathrm{C}$ were measured. The latter was transformed from $\mathrm{g}$ $\mathrm{C} \mathrm{kg}^{-1}$ to $\mathrm{kg} \mathrm{m}^{-2}$ or $\mathrm{Mg} \mathrm{ha}^{-1}$ through bulk density data.

\subsection{Statistics}

Data from all RCHs were treated with one-way ANOVA. To estimate a possible linear relationship between parameters, the Pearson's correlation coefficient was calculated. The calibration of charcoal recovery after weak nitric acid digestion was done by a linear regression model. All statistical analyses were performed with SigmaPlot 12.0 (Systat Software).

\section{Results and discussion}

\subsection{Charcoal hearths count and size}

The No and So areas were quite different in terms of RCHs number and size, as well as thickness of charcoal-rich top horizon (see S1). In No, there were three RCHs per hectare. Their mean surface was $50.8 \pm 15.1 \mathrm{~m}^{2}$ (ranging from 25 to $77 \mathrm{~m}^{2}$ ) and their charcoal-rich top horizon was $48.2 \pm 18.2 \mathrm{~cm}$ thick (ranging from 22 to $72 \mathrm{~cm}$ ). In So, there were two RCHs per hectare, with a surface of $30.5 \pm 7 \mathrm{~m}^{2}$ (ranging from 20 to $41 \mathrm{~m}^{2}$ ) and a black top horizon $24.5 \pm 10.8 \mathrm{~cm}$ thick (ranging from 11 to $41 \mathrm{~cm}$ ). The higher values of these three variables in No are in line with the apparent higher productivity of this portion of the forest compared to the other one: in fact, the higher the available biomass, the higher the charcoal production.

Number and location of RCHs depend on both environmental factors - such as available biomass, slope, aspect, soil properties (Ludemann, 2003; Schmidt et al., 2016) - and human factors - such as charcoal demand and local guidelines (Schmidt et al., 2016). Therefore, RCHs density is site specific and may vary greatly from region to region. Apart from exceptional cases where RCHs were reported to amount up to 40 per hectare (Blondel, 2006), RCHs density of one or two, as in the Marsiliana forest, are usual throughout Europe (Deforce et al., 2013; Hardy et al., 2016; Ludemann, 2010; Pèlachs et al., 2009; Py-Saragaglia et al., 2017; Raab et al., 2015; Risbøl et al., 2013).

The thickness of the black, charcoal-rich top soil horizon is chiefly linked to the lifespan of the RCHs, the frequency of carbonization, and the load of woodpiles (Carrari et al., 2017). In the literature, values range from 10 to $80 \mathrm{~cm}$, with mode at around $30 \mathrm{~cm}$. For instance, in a survey in many forest environments in Tuscany, Italy, Carrari et al. (2017) found a mean value of the thickness of the charcoal-rich horizon of $26 \mathrm{~cm}$, while in Wallonia, Belgium, Hardy et al. (2016) reported a mean value of $33.8 \mathrm{~cm}$. In the Marsiliana forest, the average thickness of the top horizon was quite high in the No area, $48.2 \mathrm{~cm}$, while in the So area it was much lower, $24.5 \mathrm{~cm}$, which is close to the above cited values.
The mean surface area of the RCHs at Marsiliana is 30 and $50 \mathrm{~m}^{2}$, in No and So, respectively, which falls within the range $27-56 \mathrm{~m}^{2}$ reported by Carrari et al. (2017) for RCHs from all over Tuscany. As terms of references, Ludemann (2010) dealt with RCHs' size ranging between 50 and $113 \mathrm{~m}^{2}$ in the German Black Forest, Pèlachs et al. (2009) with size between 64 and $95 \mathrm{~m}^{2}$ in the Spanish Pyrenees, Raab et al. (2015) with size between 133 and $660 \mathrm{~m}^{2}$ in Brandenburg, Hardy et al. (2016) with size between 50 and $78 \mathrm{~m}^{2}$ in Wallonia, while the average size of the RCHs studied by Risb $\varnothing 1$ et al. (2013) in Southern Norway was $314 \mathrm{~m}^{2}$. The relatively lower size of RCHs Carrari et al. (2017) and we measured in Tuscany compared to the above cited authors is likely due to the different supply-demand of charcoal, probably more concentrated over time in Central and Northern Europe, and to the lower productivity and/or shorter coppicing cycle in Mediterranean forests (Carrari et al., 2017; Deforce et al., 2013).

\subsection{Charcoal in the fine earth: calibration of the weak nitric acid digestion method}

The weak nitric acid digestion method showed good repeatability, the coefficient of variation for triplets of replicates being in the range 0.01-0.16 (data not shown). The calibration of the method revealed some intrinsic underestimation of charcoal (Fig. 2), which is consistent with the findings by Maestrini \& Miesel (2017) on fresh charcoal formed at temperatures lower than $550{ }^{\circ} \mathrm{C}$. Indeed, typically the temperatures inside the earth mounds are not higher than $450{ }^{\circ} \mathrm{C}$ (FAO, 1987). Moreover, the charcoal undergone an ageing process in soil could be more prone to oxidation compared to freshly produced charcoal (Cheng et al., 2014).

Consequently, the rough data obtained for charcoal- $C$ in the fine earth were adjusted according to the calibration curve, i.e. they were multiplied by the $a$ factor in the function in Fig. 2 .

\subsection{Soil organic carbon stocks}

Except for native uncharred $\mathrm{C}$, the four RCHs analysed differed from each other in terms of all the investigated variables (i.e., bulk density, fine charcoal-C, coarse charcoal-C, and TOC in fine earth and bulk soil). In particular, the RCHs with $24 \mathrm{~cm}$ thick top horizon in So $\left(\mathrm{K}_{24}\right)$ showed the highest values of TOC and total charcoal-C, both as fine and coarse fragments, compared to the other three RCHs (Table 2).

We did not find any significant correlation by the Pearson's test between the thickness of the charcoal-rich horizon and all the other investigated variables in RCHs (data not shown). In particular, contrary to our hypothesis, such thickness was not related to the concentration of the fine charcoal or the coarse one, or their sum. In addition, in the RCHs we did not find any apparent pattern in the spatial variability of the thickness of the charcoal-rich horizon or its charcoal content.

Total charcoal-C (i.e. the carbon from both coarse and fine charcoal fragments) ranged between $37 \%$ and $48 \%$ of TOC in RCHs (Table 2). On average, it amounted to $4.3-12.8 \mathrm{~kg} \mathrm{C} \mathrm{m}^{-2}$, varying with the thickness of the charcoal-rich top horizon $(13-26 \mathrm{~cm})$. Criscuoli et al. (2014) reported much higher contributions from an alpine environment, i.e. $90 \%$ of TOC and $23.3 \mathrm{~kg}$ charcoal-C $\mathrm{m}^{-2}$ in a $19 \mathrm{~cm}$ thick top horizon. On the other hand, quite lower charcoal quantities in RCHs were measured by Borchard et al. (2014) in two forests in Germany -4.1 and $6.7 \mathrm{~kg} \mathrm{C} \mathrm{m}^{-2}$ in a $20 \mathrm{~cm}$ thick top horizon - and Kerré et al. (2016) in a cropland from Belgium $-6.7 \mathrm{~kg} \mathrm{C} \mathrm{m}^{-2}$ in $23 \mathrm{~cm}$ thick top horizon - but in both cases charcoal in the skeleton was discarded. Actually, at our study site, the amount of coarse charcoal-C in RCHs was substantial, about $60 \%$ of total charcoal-C (calculated based on assessed average $\mathrm{C}$ content of coarse charcoal of $60.2 \%)$. This means that if we ignored the coarse fraction of charcoal, 


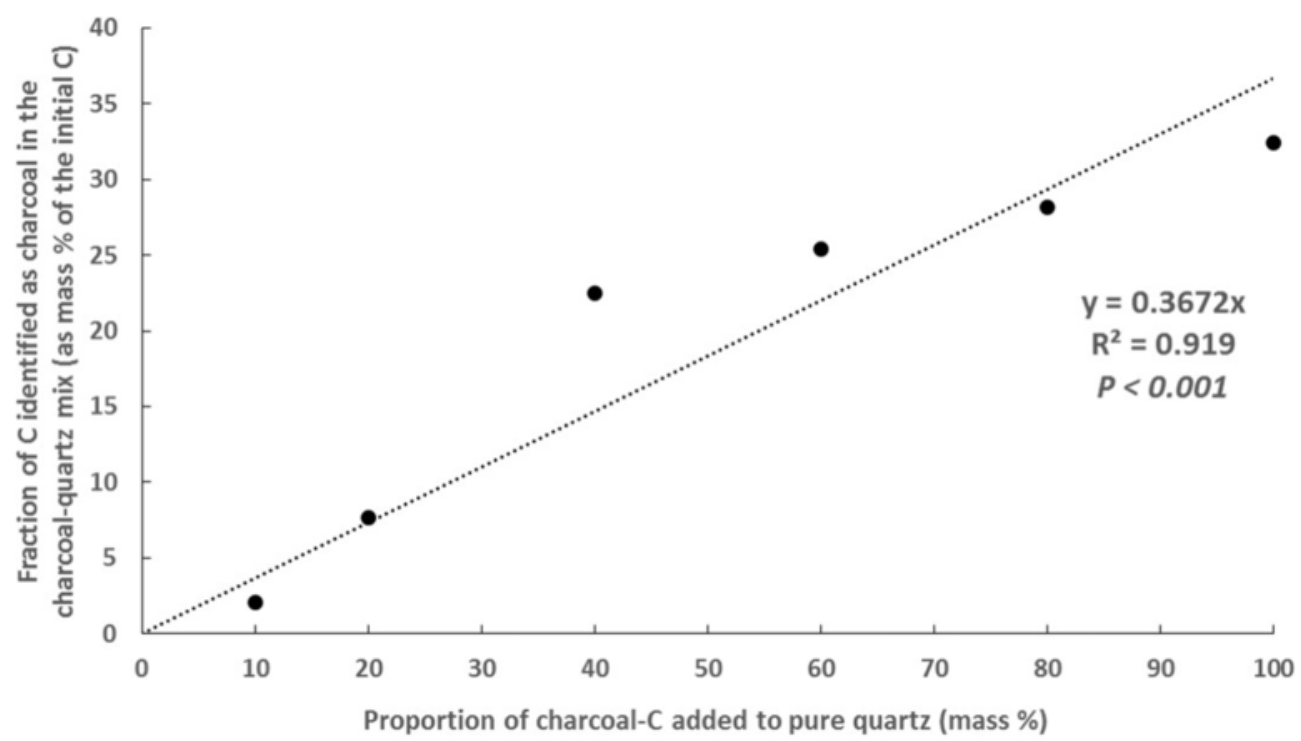

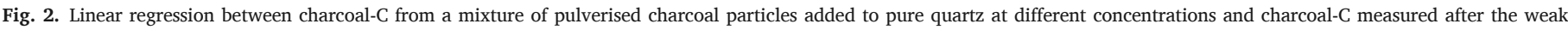
nitric acid digestion method.

our results would have been similar to the ones by Borchard et al. (2014) and Kerré et al. (2016).

For each of the investigated features, we found very different values inside and outside the RCHs (Table 2). Soils inside the RCHs included less stones compared to the surroundings soils ( $24 \%$ vs. $51 \%$ of soil dry mass, respectively). Bulk density was about $26 \%$ lower inside than outside, on average, while total organic carbon (TOC) was about one order of magnitude higher inside than outside (119-151 vs. $11-25 \mathrm{~g} \mathrm{C} \mathrm{kg}^{-1}$ bulk soil). These differences were chiefly due to the massive presence of charcoal in RCHs, while out of them there were just minor concentrations of charcoal, mostly fine: $0.4-2.4$ charcoal- $\mathrm{kg}^{-1}$ bulk soil, i.e. about $7 \%$ of TOC. This finding supports no or minor drift of charcoal from the RCHs.

The difference in charcoal-C content, however, did not account entirely for the great difference in terms of TOC between the RCHs and the surrounding soil, which was due to native uncharred $\mathrm{C}$ as well. This latter in fact amounted to $67-78 \mathrm{~g} \mathrm{C} \mathrm{kg}^{-1}$ in RCHs (about $57 \%$ of TOC) and just to $11-22 \mathrm{~g} \mathrm{C} \mathrm{kg}^{-1}$ out of them (about 93\% of TOC). Such marked difference could mean that charcoal have promoted accumulation of uncharred organic matter in RCHs and/or prevented its loss (via degradation or leaching). This hypothesis does not match the findings of Wardle et al. (2008), who dealt with charcoal-induced loss of forest humus in the mid-term, i.e. ten years, but is in agreement with the ones by several other authors in the long-term (Borchard et al., 2014; Hardy et al., 2017, Hernandez-Soriano et al., 2016, Kerré et al., 2016, 2017). In particular, Kerré et al. (2017) verified that charcoal in RCHs, in fields now cultivated with maize, actually favoured $\mathrm{C}$ accumulation and reduced the loss of dissolved $\mathrm{C}$ by adsorbing it. Hernandez-Soriano et al. (2016) suggested that charcoal might promote physical protection of uncharred organic matter within micro-aggregates. Borchard et al. (2014) found up to 3.4 times higher contents of native uncharred $C$ in RCHs compared to the surrounding soil and advanced that charcoal entrapped native $\mathrm{C}$ into its pores, so ensuring protection from decay. However, we did not find a strict correlation between native $C$ and charcoal C in RCHs (data not shown), as other studies did (Borchard et al., 2014; Kerré et al., 2016). This could be due to a sort of "saturation effect" preventing further native SOC accumulation. In fact, Borchard et al. (2014) found that such an accumulation of native uncharred $\mathrm{C}$ stopped for charcoal-C content higher than 4-8 $\mathrm{kg} \mathrm{C} \mathrm{m}^{-2}$.

\subsection{Forest $C$ pools}

The merchantable volume $(V)$ of timber was heterogeneous throughout the forest, as inferred from the Forest Management Plan of Marsiliana (Table 1). On average, $V$ was $150 \mathrm{~m}^{3} \mathrm{ha}^{-1}$ in the No area and $75 \mathrm{~m}^{3} \mathrm{ha}^{-1}$ in So. This large difference was due to different forest productivities in the two aspects, but also to the younger age of the forest in So (Table 1). According to Eq. (1) biomass C was 113.5 and $56.8 \mathrm{Mg}$ $\mathrm{C} \mathrm{ha}{ }^{-1}$ in No and So, respectively (Table 3 ).

Necromass $C$ was estimated on the basis of the last Italian national forest inventory (INFC, 2011), which for this type of ecosystem reported $1 \mathrm{MgC} \mathrm{ha}^{-1}$. This value was applied to both No and So. Litter amounted to $15.2 \pm 4.7$ and $12.8 \pm 4.4 \mathrm{Mg} \mathrm{ha}^{-1}$ in No and So, respectively, while the average $\mathrm{C}$ concentration in the litter was $35.7 \%$. As a consequence, the litter $\mathrm{C}$ pool amounted to 5.4 and $4.6 \mathrm{Mg} \mathrm{C} \mathrm{ha}^{-1}$ in No and So, respectively (Table 3).

According to the above cited forest national inventory (INFC, 2011) we took into account just the top $30 \mathrm{~cm}$ of mineral soil for calculating the soil C stock outside the RCHs. In such a calculation, the collective surface of RCHs was subtracted from the forest's total surface and the C stock of the RCHs was calculated separately for No and So. It was done multiplying the average TOC content for the average surface area of RCHs and for the average thickness of the charcoal-rich top horizon. Hence, in No, where RCHs had average surface of $50.8 \mathrm{~m}^{2}$ and a top horizon $48.2 \mathrm{~cm}$ thick, they overall stored $2.5 \mathrm{Mg} \mathrm{C}$, i.e. $7.5 \mathrm{Mg} \mathrm{C}^{-1}$ - there being on average three RCHs per hectare - while the rest of soil stored $49.6 \mathrm{Mg} \mathrm{Cha}^{-1}$ (Table 2). In So, RCHs, which had average surface of $30.5 \mathrm{~m}^{2}$ and a top horizon $24.5 \mathrm{~cm}$ thick, overall stored $0.7 \mathrm{Mg}$ C, i.e. $1.5 \mathrm{Mg} \mathrm{C}^{-1}$, - there being on average two RCHs per hectare - while the rest of soil stored 75.4 $\mathrm{Mg} \mathrm{C}^{-1}$ (Table 2).

Biomass and soil were the largest $\mathrm{C}$ reservoirs in the Marsiliana forest (Fig. 3). However, the No and So areas showed some major differences. In fact, in So soil stored $54 \%$ of total ecosystem C, while in No the soil contribution in terms of $\mathrm{C}$ was just $28 \%$. The contribution of the litter-C to TOC was similar in No and So, about $3 \%$, which was about 3 times higher than the estimated one of deadwood-C. The contribution of $\mathrm{C}$ in RCHs to total ecosystem $\mathrm{C}$ was substantially different in the two areas: $4.2 \%$ in No and $1.1 \%$ in So. Nonetheless, both of 
Table 2

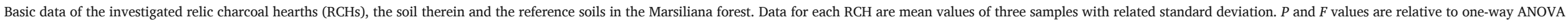
analysis between all hearths. $P$ values in bold are smaller than 0.05 .

\begin{tabular}{|c|c|c|c|c|c|c|c|c|c|c|}
\hline $\begin{array}{l}\text { Study area/ } \\
\text { Hearth }\end{array}$ & $\begin{array}{l}\text { Thickness of top } \\
\text { layer }\end{array}$ & Area & $\begin{array}{l}\text { Bulk } \\
\text { density }\end{array}$ & $\begin{array}{l}\text { Native uncharred } \\
\mathrm{C}\end{array}$ & $\begin{array}{l}\text { Fine charcoal- } \\
\text { C }\end{array}$ & Coarse charcoal-C & $\begin{array}{l}\text { Total charcoal- } \\
\text { C }\end{array}$ & $\begin{array}{l}\text { TOC in bulk } \\
\text { soil }\end{array}$ & $\begin{array}{l}\text { TOC in bulk } \\
\text { soil }\end{array}$ & $\begin{array}{l}\text { Total charcoal- } \\
\text { C }\end{array}$ \\
\hline & $\mathrm{cm}$ & $\mathrm{m}^{2}$ & $\mathrm{~kg} \mathrm{dm}^{3}$ & $\mathrm{~g} \mathrm{~kg}^{-1}$ & $\mathrm{~g} \mathrm{~kg}^{-1}$ & $\mathrm{~g} \mathrm{~kg}^{-1}$ & $\mathrm{~g} \mathrm{~kg}^{-1}$ & $\mathrm{~g} \mathrm{~kg}^{-1}$ & $\mathrm{~kg} \mathrm{~m}^{-2}$ & $\%$ \\
\hline \multicolumn{11}{|l|}{ No area } \\
\hline $\mathrm{H}_{22}$ & 22.0 & 33 & 0.9 & 71.8 & 15.9 & 31.8 & 47.7 & 119.5 & 23.6 & 39.7 \\
\hline Standard dev. & 2.6 & & 0.0 & 7.1 & 6.2 & 3.7 & 9.9 & 13.9 & 3.8 & 3.9 \\
\hline Reference soil & - & - & 1.0 & 11.1 & 0.4 & 0.0 & 0.4 & 11.5 & 2.5 & 3.6 \\
\hline \multicolumn{11}{|l|}{$\mathrm{H}_{22}$} \\
\hline $\mathrm{H}_{26}$ & 26.4 & 60.3 & 0.8 & 67.2 & 23.6 & 33.2 & 56.8 & 124.0 & 25.4 & 45.7 \\
\hline Standard dev. & 3.3 & & 0.0 & 1.7 & 1.5 & 4.3 & 5.8 & 4.2 & 3.6 & 3.1 \\
\hline Reference soil & - & - & 1.3 & 15.9 & 1.9 & 0.0 & 1.9 & 17.8 & 5.9 & 10.5 \\
\hline $\begin{array}{l}\text { So area } \\
\mathrm{H}_{13}\end{array}$ & 12.7 & 27.5 & 0.8 & 77.7 & 19.0 & 26.1 & 45.2 & 122.9 & 11.8 & 37.0 \\
\hline Standard dev. & 1.3 & & 0.1 & 11.7 & 1.4 & 3.5 & 4.9 & 9.3 & 2.5 & 4.9 \\
\hline Reference soil & - & - & 1.2 & 16.8 & 0.9 & 0.0 & 0.9 & 17.7 & 2.7 & 5.2 \\
\hline \multicolumn{11}{|l|}{$\mathrm{H}_{13}$} \\
\hline $\mathrm{H}_{24}$ & 23.7 & 19.6 & 0.7 & 77.1 & 30.7 & 43.3 & 74.0 & 151.0 & 26.1 & 48.7 \\
\hline Standard dev. & 4.3 & & 0.0 & 2.3 & 6.8 & 9.0 & 15.9 & 11.5 & 3.5 & 5.1 \\
\hline Reference soil & - & - & 1.2 & 22.3 & 2.4 & 0.0 & 2.4 & 24.7 & 6.7 & 9.6 \\
\hline \multicolumn{11}{|l|}{$\mathrm{H}_{24}$} \\
\hline $\mathrm{P}$ value & & & 0.008 & 0.293 & 0.047 & 0.033 & 0.014 & 0.020 & & \\
\hline $\mathrm{F}$ value & & & 8.18 & 1.476 & 4.170 & 4.862 & 6.684 & 5.935 & & \\
\hline
\end{tabular}


Table 3

Total organic C in the north-oriented (No) and south-oriented (So) areas in the Marsiliana forest and contributions of different C pools. The "Soil C in RCHs" (relic charcoal hearths) pool is further divided in three fractions: native uncharred C, fine charcoal C, and coarse charcoal C.

\begin{tabular}{|c|c|c|c|c|}
\hline & No area & & So area & \\
\hline & $\begin{array}{l}\mathrm{Mg} \\
\mathrm{C} \mathrm{ha}^{-1}\end{array}$ & $\begin{array}{l}\% \text { of } \\
\text { total }\end{array}$ & $\begin{array}{l}\mathrm{Mg} \\
\mathrm{C} \mathrm{ha} \\
-1\end{array}$ & $\begin{array}{l}\% \text { of } \\
\text { total }\end{array}$ \\
\hline Forest TOC & 177.1 & & 139.3 & \\
\hline Biomass C & 113.5 & 64.1 & 56.8 & 40.8 \\
\hline $\begin{array}{l}\text { Soil C out of } \\
\text { RCHs }\end{array}$ & 49.6 & 28 & 75.4 & 54.1 \\
\hline Deadwood C & 1 & 0.6 & 1 & 0.7 \\
\hline Litter C & 5.4 & 3.1 & 4.6 & 3.3 \\
\hline Soil C in RCHs & 7.5 & 4.2 & 1.5 & 1.1 \\
\hline $\begin{array}{l}\text { Native } \\
\text { uncharred C }\end{array}$ & 4.3 & 2.4 & 0.9 & 0.6 \\
\hline Fine charcoal C & 1.2 & 0.7 & 0.3 & 0.2 \\
\hline $\begin{array}{l}\text { Coarse } \\
\text { charcoal C }\end{array}$ & 2.0 & 1.1 & 0.4 & 0.3 \\
\hline
\end{tabular}

these values demonstrate that carbon in RCHs is a relevant pool that cannot be neglected in a $C$ inventory.

Different forms of carbon have of course different residence time. Therefore, despite $\mathrm{C}$ inventories do not make any distinction in this regard, the positive contribution of RCHs as C stock is even more relevant, since charcoal has very long residence time in soil, even centuries or millennia (Schmidt \& Noack, 2000). In the Marsiliana forest, such highly stable C fraction was one third of TOC in RCHs, i.e. $1.8 \%$ and $0.5 \%$ of ecosystem $\mathrm{C}$ in the No and So areas, respectively.

\subsection{Significance and implications of the study}

The results we obtained in the Marsiliana forest cannot be fully extended to other environments, because many factors vary from place to place and similar studies in other locations are needed. The latter have to comprise the quantification of the coarse charcoal, whose isolation from the rock fragments is neither much time consuming nor expensive.

Despite the variability of properties that hearth sites can show at local level, some features of RCHs at our study site, such as density and surface area, the thickness of the charcoal-rich horizon, and the charcoal-C stock, were not much different as a whole from the ones reported by other authors for Italy and other sides of Europe. Therefore, those forests where charcoal production was massive in the past - that is actually the case for many regions in Europe - should show a significant $\mathrm{C}$ stock in the RCHs. The relative contribution of such a stock to the whole $C$ stock of the forest would show the same order of magnitude of that found at our study site, at least in those forests having comparable soil and biomass $\mathrm{C}$ stocks. In this regard, the mean aboveground biomass of Italian forests is $101 \mathrm{Mg} \mathrm{ha}^{-1}$, which drops to $70 \mathrm{Mg} \mathrm{ha}^{-1}$ in the case of evergreen oak forests (INFC, 2011). These values are comparable to those of the Marsiliana forest, where the aboveground biomass amounted to 108 and $54 \mathrm{Mg} \mathrm{ha}{ }^{-1}$ (calculated as the merchantable volume divided per the mean wood density) in No and So, respectively. Also, the soil C stocks in No and So -75 and $50 \mathrm{Mg} \mathrm{C}^{-1}$, respectively - are similar to the mean values reported by the national inventory (INFC, 2011) for the first $30 \mathrm{~cm}$ of soil in evergreen oak forests, i.e. $72 \mathrm{MgCha}{ }^{-1}$, and in forests in general, i.e. $76 \mathrm{MgC} \mathrm{ha}^{-1}$.

\section{Conclusions}

This study proved that in the Mediterranean oak forest of Marsiliana, relic charcoal hearths are "hotspots" in terms of soil organic carbon, being even to eight times richer than the surrounding soils. A large part of soil C in the hearths is charcoal, which has long residence time, hence emphasising the positive role of these anthropogenic soils in terms of $\mathrm{C}$ reservoirs. Moreover, our data suggest that charcoal promoted accumulation of native (uncharred) soil organic matter in hearths.
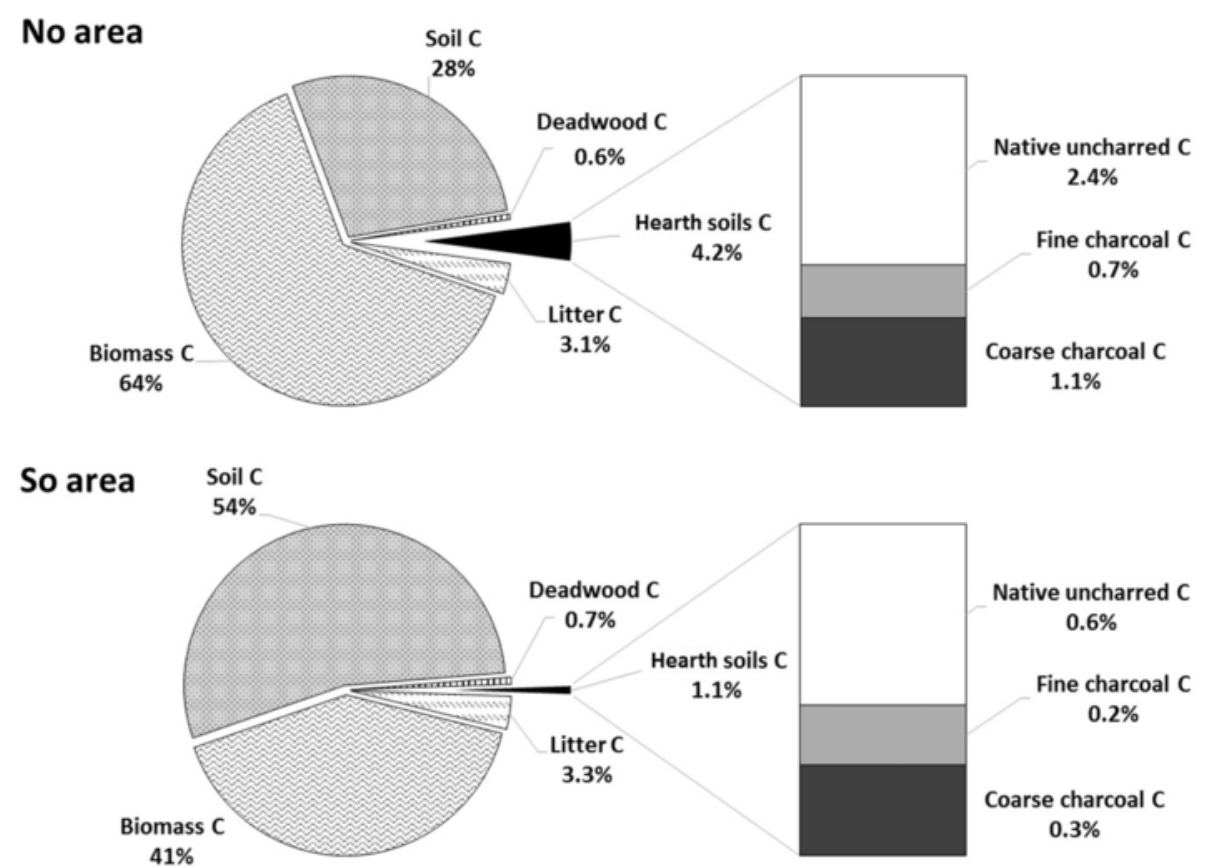

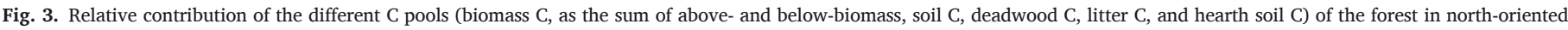

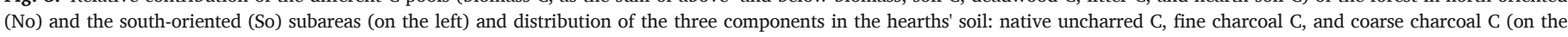
right). 
Although relic charcoal hearths occupied $<0.5 \%$ of the total surface of the forest, their overall contribution to the ecosystem carbon stock was definitely higher, $1.1 \%$ or $4.2 \%$ according to the aspect of the subarea investigated (north or south oriented). Such contributions are of the order of magnitude of those of deadwood or litter. This highlights the need of taking into account charcoal hearths in local or regional inventories of terrestrial $\mathrm{C}$ pools.

The results of this study cannot be fully extended to other environments, being the occurrence, density, extent, thickness, and state of conservation of relic charcoal hearths site sensitive. As a consequence, future studies aimed at measuring these variables of relic charcoal hearths - as well as their charcoal content - in other sites from all around the world are welcome. They will serve to raise awareness that relic charcoal hearths deserve to be preserved as both a precious legacy of a fundamental activity of the past, throughout Europe and elsewhere, and a significant reservoir of $\mathrm{C}$ with long residence time in soil.

Supplementary data to this article can be found online at https:// doi.org/10.1016/j.geoderma.2017.11.036.

\section{Acknowledgements}

The authors thanks Elisa Carrari, Cristiana Brogi, and Martina Venturi for fruitful discussions and support during fieldwork, and Paola Gioacchini for help with elemental analysis. Special thanks to Alessandro Samola and the 'Unione di Comuni Montana Colline Metallifere' for providing crucial information on the study area. Last, but not least, the authors are in debt to Davide Mastrolonardo, who kindly drew the graphical abstract. The first author, G.M., is a Marie-Curie COFOUND postdoctoral fellow, co-founded by the European Commission and the University of Liege (ref. number: 600405).

\section{References}

Antal, M.J., Grønli, M., 2003. The art, science, and technology of charcoal production. Ind. Eng. Chem. Res. 42, 1619-1640.

Bird, M.I., Ascough, P.L., 2012. Isotopes in pyrogenic carbon: a review. Org. Geochem. 42, $1529-1539$.

Blake, G.R., Hartge, K.H., 1986. Bulk density. In: Klute, A. (Ed.), Methods of Soil Analysis. Part I. Physical and Mineralogical Methods. Soil Science Society of America, Inc., Madison, WI, pp. 363-376.

Blondel, J., 2006. The "design" of Mediterranean landscapes: a millennial story of humans and ecological systems during the historic period. Hum. Ecol. 34, 713-729.

Borchard, N., Ladd, B., Eschemann, S., Hegenberg, D., Möseler, B.M., Amelung, W., 2014. Black carbon and soil properties at historical charcoal production sites in Germany. Geoderma 232-234, 236-242.

Carrari, E., Ampoorter, E., Verheyen, K., Coppi, A., Selvi, F., Ewald, J., 2016. Former charcoal kiln platforms as microhabitats affecting understorey vegetation in Mediterranean forests. Appl. Veg. Sci. 19, 486-497.

Carrari, E., Ampoorter, E., Verheyen, K., Coppi, A., Selvi, F., 2016. Former charcoal platforms in Mediterranean forest areas: a hostile microhabitat for the recolonization by woody species. iForest - Biogeosci. For. 9, 136-144.

Carrari, E., Ampoorter, E., Bottalico, F., Chirici, G., Coppi, A., Travaglini, D., Verheyen, K., Selvi, F., 2017. The old charcoal kiln sites in Central Italian forest landscapes. Quat. Int. 458, 214-223.

Cheng, C.-H., Lin, T.-P., Lehmann, J., Fang, L.-J., Yang, Y.-W., Menyailo, O.V., Chang, K.-H., Lai, J.-S., 2014. Sorption properties for black carbon (wood char) after long term exposure in soils. Org. Geochem. 70, 53-61.

Costagliola, P., Benvenuti, M., Chiarantini, L., Bianchi, S., Di Benedetto, F., Paolieri, M., Rossato, L., 2008. Impact of ancient metal smelting on arsenic pollution in the Pecora River Valley, Southern Tuscany, Italy. Appl. Geochem. 23, 1241-1259.

Criscuoli, I., Alberti, G., Baronti, S., Favilli, F., Martinez, C., Calzolari, C., et al., 2014. Carbon sequestration and fertility after centennial time scale incorporation of charcoal into soil. PLoS One 9, e91114.

Currie, L.A., Benner, B.A., Kessler, J.D., Klinedinst, D.B., Klouda, G.A., Marolf, J.V., et al., 2002. A critical evaluation of interlaboratory data on total, elemental, and isotopic carbon in the carbonaceous particle reference material, NIST SRM 1649a. J. Res. Natl. Inst. Stand. Technol. 107, 279.

De Lafontaine, G., Asselin, H., 2011. Soil charcoal stability over the Holocene across boreal northeastern North America. Quat. Res. 76, 196-200.

Deforce, K., Boeren, I., Adriaenssens, S., Bastiaens, J., De Keersmaeker, L., Haneca, K., et al., 2013. Selective woodland exploitation for charcoal production. A detailed analysis of charcoal kiln remains (ca. 1300-1900 AD) from Zoersel (northern Belgium). J. Archaeol. Sci. 40, 681-689.
FAO, 1987. Simple Technologies for Charcoal Making. Mechanical Wood Products Branch, Forest Industries Division, FAO Forestry Paper 41, Rome.

Gratani, L., Amadori, M., Veri, L., Bruno, F., Porri, M., 1980. Determinazione di un metodo di stima della biomassa nella macchia di Castelporziano (Lazio). Ann. Bot. 41, 131-151.

Hammes, K., Schmidt, M.W.I., Smernik, R.J., Currie, L.A., Ball, W.P., Nguyen, T.H., Louchouarn, P., et al., 2007. Comparison of quantification methods to measure fire-derived (black-elemental) carbon in soils and sediments using reference materials from soil, water, sediment and the atmosphere. Glob. Biogeochem. Cycles 21, GB3016.

Hardy, B., Cornelis, J.T., Houben, D., Lambert, R., Dufey, J.E., 2016. The effect of pre-industrial charcoal kilns on chemical properties of forest soil of Wallonia, Belgium. Eur. J. Soil Sci. 67, 206-216.

Hardy, B., Cornelis, J.-T., Houben, D., Leifeld, J., Lambert, R., Dufey, J., 2017. Evaluation of the long-term effect of biochar on properties of temperate agricultural soil at pre-industrial charcoal kiln sites in Wallonia, Belgium. Eur. J. Soil Sci. 68, 80-89.

Hart, J.L., Van De Gevel, S.L., Mann, D.F., Clatterbuck, W.K., 2008. Legacy of charcoaling in a Western Highland Rim Forest in Tennessee. Am. Midl. Nat. 159, 238-250.

Heitkötter, J., Marschner, B., 2015. Interactive effects of biochar ageing in soils related to feedstock, pyrolysis temperature, and historic charcoal production. Geoderma 245-246, 56-64.

Hernandez-Soriano, M.C., Kerè, B., Goos, P., Hardy, B., Dufey, J., Smolders, E., 2016. Long-term effect of biochar on the stabilization of recent carbon: soils with historical inputs of charcoal. GCB Bioenergy 8, 371-381.

Inventario Nazionale delle Foreste e dei Serbatoi Forestali di Carbonio (INFC 2005), 2011. Secondo inventario forestale nazionale italiano. Metodi e risultati. Ministero delle Politiche Agricole, Alimentari e Forestali; Corpo Forestale dello Stato. Consiglio per la Ricerca e la Sperimentazione in Agricoltura, Unità di ricerca per il Monitoraggio e la Pianificazione Forestale. In: Gasparini, P., Tabacchi, G. (Eds.), Edagricole-Il Sole 24 ore, Bologna, (653 pp).

IUSS Working Group WRB, 2015. World Reference Base for Soil Resources 2014. Update 2015. International Soil Classification System for Naming Soils and Creating Legends for Soil Maps. World Soil Resources Reports No. 106. FAO, Rome

Kerré, B., Bravo, C.T., Leifeld, J., Cornelissen, G., Smolders, E., 2016. Historical soil amendment with charcoal increases sequestration of non-charcoal carbon: a comparison among methods of black carbon quantification. Eur. J. Soil Sci. 67, 324-331.

Kerré, B., Willaert, B., Smolders, E., 2017. Lower residue decomposition in historically charcoal-enriched soils is related to increased adsorption of organic matter. Soil Biol. Biochem. 104, 1-7.

Kurth, V.J., MacKenzie, M.D., DeLuca, T.H., 2006. Estimating charcoal content in forest mineral soils. Geoderma 137, 135-139.

Ludemann, T., 2003. Large-scale reconstruction of ancient forest vegetation by anthracology - a contribution from the Black Forest. Phytocoenologia 33, 645-666.

Ludemann, T., 2010. Past fuel wood exploitation and natural forest vegetation in the Black Forest, the Vosges and neighbouring regions in western Central Europe. Palaeogeogr. Palaeoclimatol. Palaeoecol. 291, 154-165.

Mariotti Lippi, M., Giachi, G., Paci, S., Di Tommaso, P.L., 2000. Studi sulla vegetazione attuale e passata della Toscana meridionale (Follonica-Italia) e considerazioni sull'impatto ambientale dell'attività metallurgica etrusca nel VI—V secolo a.C. Webbia. 55, 279-295.

Mikan, C.J., Abrams, M.D., 1995. Altered forest composition and soil properties of historic charcoal hearths in southeastern Pennsylvania. Can. J. For. Res. 25, 687-696.

Mikan, C.J., Abrams, M.D., 1996. Mechanism inhibiting the forest development of historic charcoal hearths in southeastern Pennsylvania. Can. J. For. Res. 26, 1893-1898.

Pèlachs, A., Nadal, J., Soriano, J.M., Molina, D., Cunill, R., 2009. Changes in pyrenean woodlands as a result of the intensity of human exploitation: 2,000 years of metallurgy in Vallferrera, northeast iberian peninsula. Veg. Hist. Archaeobotany 18, 403-416.

Penman, J., Gytarski, M., Hiraishi, T., Krug, T., Kruger, D., Pipatti, R., Buendia, L., Miwa, K., et al., 2003. Good Practice Guidance for Land Use, Land-use Change and Forestry. Intergovernmental Panel on Climate Change. IPCC National Greenhouse Gas Inventories Programme and Institute for Global Environmental Strategies, Kanagawa, Japan.

Py-Saragaglia, V., Cunill Artigas, R., Métailié, J.P., Ancel, B., Baron, S., Paradis-Grenouillet, S., Lerigoleur, Émilie, Badache, N., Barcet, H., Galop, D., 2017. Late Holocene history of woodland dynamics and wood use in an ancient mining area of the Pyrenees (Ariège, France). Quat. Int. 458, 141-157.

Raab, A., Takla, M., Raab, T., Nicolay, A., Schneider, A., Rösler, H., et al., 2015. Pre-industrial charcoal production in Lower Lusatia (Brandenburg, Germany): detection and evaluation of a large charcoal-burning field by combining archaeological studies, GIS-based analyses of shaded-relief maps and dendrochronological age determination. Quat. Int. 367, 111-122.

Raab, T., Hirsch, F., Ouimet, W., Johnson, K., Dethier, D., Raab, A., 2017. Architecture of relict charcoal hearths in Northwestern Connecticut, USA. Geoarchaeology 32, 502-510.

Roth, P.J., Lehndorff, E., Brodowski, S., Bornemann, L., Sanchez-García, L., Gustafsson, , Amelung, W., 2012. Differentiation of charcoal, soot and diagenetic carbon in soil: method comparison and perspectives. Org. Geochem. 46, 66-75.

Schenkel, Y., Bertaux, P., Vanwijnbserghe, S., Carre, J., 1998. An evaluation of the mound kiln carbonization technique. Biomass Bioenergy 14, 505-516.

Schmidt, M.W.I., Noack, A.G., 2000. Black carbon in soils and sediments: analysis, distribution, implications, and current challenges. Glob. Biogeochem. Cycles 14, 777-793. 
Schmidt, M., Mölder, A., Schönfelder, E., Engel, F., Fortmann-Valtink, W., 2016. Charcoal kiln sites, associated landscape attributes and historic forest conditions: DTM-based investigations in Hesse (Germany). For. Ecosyst. 3, 8.

Vitullo, M., De Lauretis, R., Federici, S., 2008. La contabilità del carbonio contenuto nelle foreste italiane. Silvae 9, 91-104.
Wardle, D.A., Nilsson, M.-C., Zackrisson, O., 2008. Fire-derived charcoal causes loss of forest humus. Science 320, 629.

Young, M.J., Johnson, J.E., Abrams, M.D., 1996. Vegetative and edaphic characteristics on relic charcoal hearths in the Appalachian mountains. Vegetatio 125, 43-50. 